\title{
The International Cooperation at STKIP Weetebula based on Hofstede's Culture Dimensions
}

\author{
Wilhelmus Yape Kii 1) \\ 1) Dosen Program Studi Pendidikan IPA STKIP Weetebula
}

* Wilhelmus Yape Kii, Dosen Program Studi Pendidikan IPA, STKIP Weetebula; Email:

\section{Introduction}

\subsection{Definition of Culture}

In Bahasa, the word culture derives from Sanskrit the "buddhayah", which is the plural form of buddhi (mind or intellect). Culture is defined as matters relating to the human mind. In English, the word come from the Latin word "colere", which means processing or working. It also can be interpreted as cultivating the land or working the land, maintaining the fields, so that culture can be interpreted as all human activities to cultivate and change nature (Nasution and Albani, 2015; 16-17).

There are many definitions of culture. Some experts provide the following definition: Kroeber and Kluckhons explain that "culture consists of patterns, explicit and implicit of and for the behavior of patterns, the constituting the distinctive achievements of human groups, including their embodiment in artefact; the essential core of culture consists of their ideas and especially their attached values; Culture is closely related to society. Melville J. Herskovits and Bronislaw Malinowski argue that everything contained in society is determined by culture which is owned by the society itself, known as cultural determinism (in Nasution and Albani, 2015, 16-17). Edward Burnett Taylor interprets the meaning of culture from a person's point of view as a part of a community. Taylor stated that culture is the whole complex, within which is contained knowledge, beliefs, arts, morals, laws, customs, and other abilities that a person acquires as a member of society (in Jenks C., 2013, 42). From these definitions, it can be said that culture is something that will affect the level of knowledge, includes the systems, ideas (contained in the human mind) developed and shared by a group of people, an identity for a community, and passed from generation to generation.

Cultural manifestations are objects created by human beings as cultured beings, in the form of behaviours and objects of a real nature, such as patterns of behaviour, language, tools of life, social organization, religion, art, all of which aimed at 
helping humans in social life. One model that used to describe the extent and depth of culture definition is the iceberg model. This model shows two main concepts of culture, the visible and invisible. There are some elements of culture that can be seen in the physical sense. Some example of visible elements that can be found in a country or culture such as dress, dance, architecture, language, food, gestures, greetings, behaviour, devotional practices, art, and ceremonial (birth, married, burial). These visible elements are driven by the invisible elements. As the invisible elements can be defined as the underlying causes of visible elements. Invisible elements comprise of religious beliefs, world views, rules of relation, motivation, tolerance, attitude to rules, communication styles, way of thinking, risk tolerance, gender issues.

\subsection{The definition of Cross Culture and Multicultural}

Cross culture dealing with or offering comparison between two or more different cultures or cultural areas. When comparing the two different cultures, it is important to consider what are the elements that make the culture. According to C. Kluckhohn (in Nasution and Albani, 2015) there are 7 elements of culture:

1. Belief system is a very important element in life. It has function to regulate life between human and the Creator.

2. System of knowledge has a function to fulfil human curiosity of knowledge. Human will meet the needs of their life with the system of knowledge.

3. System of technology. System of technology includes all equipment that human needs and uses for life.

4. Community system is a very important cultural inheritance in a social structure.

5. System of economics. The economic system cultural element relates to the livelihood of traditional society. Those livelihoods include hunting and gathering, farming, and catching fish.

6. Language. Language is an element of culture that use to communicate, direct (orally), and indirect (writing, or in gesture).

7. Art. Art is the last element that focuses on the value of beauty created by human.

Considering these seven aspects of culture, in this paper, I will highlight the sixth element of culture, language, as the key to work in a context of multicultural workplace. Language is used to communicate directly and indirectly both by people from the same culture and different cultures. However, language differences can arise problem, such as misunderstanding the meaning of a word of a phrase, as well as the different styles of using language. The communication between people from different cultures (languages, racial, ethnic, or socioeconomic, or a mixture of all these differences) normally happen these days. Understanding cross-cultural communication is important for the practice of having diverse workforce or plans on globalisation as human flow across national boundaries.

Culture is important for many aspects of education institution especially when an education institution must deal with people, either as lecturers, staffs, students, parents or other stakeholders. Cross-cultural communication has played important value in education institution especially when many people from different culture background are involved and it has been able to provide substance to modern management practices and techniques.

\section{Cultural Dimension}

\subsection{Hofstede's Cultural Dimensions}

Hofstede (1994) defines culture as human thoughts, feelings, and actions. According to Hofstede, culture is the software of the human soul or 'software of the mind.' Hofstede uses the parable of a computer unit to explain the role of culture in human life. The computer software is determining the working of a computer, without software, the computer is useless. Hofstede wants to state the importance of culture by using the parable 'software of the mind'. Culture is the driving force of human. Without the driving force, humans are just beings without meaning. Culture is constantly evolving, this shows that the phenomenon of culture definitions is never end. 
Culture is one of the topics that interest researchers from diverse disciplines. This is because culture is one of the external factors that influence every human behaviour (Maheswaran and Shavitt, 2000). A person is not born with a cultural understanding, but the person will learn about the culture through the process of acculturation and enculturation. How the person has a way of looking and behaving is influenced by the culture.

To measure the culture, social researchers normally using the cultural dimensions developed by Hofstede (1980) and Hofstede and Bond (1988). These dimensions are: power distance, individualism/collectivism, uncertainty avoidance, and masculinity/femininity. Independent research in Hongkong led Hofstede to add a fifth dimension, long-term orientation, to cover aspects of values that are not discussed in the original paradigm. In 2010, Hofstede added a sixth dimension, indulgence versus self-restraint (Kirkman et al., 2006).

Hofstede (1994) collect data from various countries with the following characteristics. Firstly, the country has one dominant language, for example Indonesian for the Indonesian state. Secondly, has a national education system. Finally, the country has a national political system. Thus, that data obtained from a country, such as Indonesia, can be said to be typical of Indonesia. Or, data obtained from the German state, can be said to be typical of Germany. Research conducted by Hofstede using IBM workers as respondents.

\subsection{The Cultural Dimension of Germany and Indonesia}

Germans and Indonesia have been selected as two countries to illustrate Hofstede's dimensions because persons that work at STKIP Weetebula are coming from these two countries. There seems to be some cultural gaps between these countries. This paper discusses the cultural comparison of people from Germany and Indonesia. Comparison is made by looking at the score obtained from each country for each dimension. For this case of description, the country scenarios will be examined from the situation of German's experts working in Sumba (Indonesia). Table 1 shows the score the Germans compared to the Indonesians based on Hofstede's cultural dimensions.
Table 1. Germany and Indonesia cultural dimensions (Summary from Hofstede, 1994).

\begin{tabular}{|c|c|c|c|c|c|}
\hline \multirow{2}{*}{$\mathbf{N}$} & \multirow[b]{2}{*}{$\begin{array}{c}\text { Culture } \\
\text { Dimensions }\end{array}$} & \multicolumn{2}{|c|}{ Germany } & \multicolumn{2}{|c|}{ Indonesia } \\
\hline & & $\begin{array}{l}\text { Ra } \\
\text { nk }\end{array}$ & $\begin{array}{l}\text { Sco } \\
\text { re }\end{array}$ & $\begin{array}{l}\text { Ra } \\
\text { nk }\end{array}$ & $\begin{array}{c}\text { Sco } \\
\text { re }\end{array}$ \\
\hline 1 & Power Distance & 42 & 35 & 8 & 78 \\
\hline 2 & $\begin{array}{l}\text { Individualism/Colle } \\
\text { ctivism }\end{array}$ & 15 & 67 & 47 & 14 \\
\hline 3 & $\begin{array}{l}\text { Uncertainty } \\
\text { Avoidance }\end{array}$ & 29 & 65 & 41 & 48 \\
\hline 4 & $\begin{array}{l}\text { Masculinity/Femini } \\
\text { nity }\end{array}$ & 10 & 66 & 31 & 46 \\
\hline
\end{tabular}

Based on Table 1, Indonesia is a country that is categorized as High-Power Distance, Collectivism, Low Uncertainty Avoidance, and Femininity. On the other hand, Germany includes Low Power Distance, Individualism, High Uncertainty Avoidance, and Masculinity.

Power Distance (PD) is defined as how much of an imbalance occurs in society. One example of a great Power Distance value is children must obey parents and teachers while children in Germany (a country with a Small Power Distance value) treat parents and teachers to balance with themselves. Individualism/Collectivism dimension describes how close the relationship between individuals in society. Indonesia with a collectivism value indicates that the relationship between individuals in society is close. This close relationship lays harmony as the key in maintaining relationships (Sihombing and Pongtuluran, 2011).

Furthermore, Uncertainty Avoidance is a tolerance for obscurity. In this dimension, Indonesia ranks slightly lower than Germany. The higher rank means that Germany has a clear commitment by following the rules (Hofstede, 1994).

Finally, Masculinity is concerned with differences in gender roles and individual preferences. Countries with high Masculinity scores clearly distinguish that men should be more aggressive than women. Men should focus on material success and women should be simpler and pay attention to quality of life. On the other hand, countries with Femininity values have the view that men and women should be simple and pay attention to the quality of life. Masculinity also deals with individual preferences in society. Countries with Masculinity emphasize on achieving heroic and assertive values. Conversely, countries with 
Femininity dimension emphasize individuals to maintain relationships, that is by paying attention to others (Hofstede, 1994). Based on the Hofstede score's, Indonesia tend to be Femininity dimension country, However, Indonesia has some aspects of the Masculinity dimension, for example men are the most responsible in the family while women are responsible for taking care of the child and home life. In addition, works means relation, solidarity, but less women in management levels while in Germany work means security, good payment, competition, but more women in management levels (Liliweri, 2003, 120-127). Hofstede's study shows that on two dimensions, the Uncertainty Avoidance and Masculinity/Femininity both Germany and Indonesia have a close score, while the other 2 cultural dimensions, both countries are in opposite positions.

Hofstede's dimensions are often used in social research because of their simplicity in understanding when measuring culture (Kirkman et al., 2006). His work on culture is the most widely cited and his ideas are considered a highly valuable insight into the dynamics of cross-cultural relationships (Jones, 2007). In some aspects, Hofstede's study has also received criticisms such as: (1) reducing culture in 4 or 5 dimensions (Jones, 2007), (2) old studies that conducted in 1967-1973 (Jones, 2007; Steenkamp et al., 1999); and (3) measuring cultures using work-related values (Steenkamp et al., 1999).

Cultural understanding and measurement are still and continue to be relevant today. As de Mooij (2004) points out that although people look the same, but their thinking and behaviour are different in each region.

\section{The international cooperation at STKIP Weetebula STKIP Weetebula}

STKIP (Higher College for Teacher Candidate) is a Teacher Training and Pedagogical College, established by the District of Southwest Sumba, Bishop of Weetebula and YAPNUSDA in 2009. STKIP Weetebula has a 100-ha campus and located in Karuni Village, Loura Sub-District, Southwest Sumba District. The campus is about 6 $\mathrm{km}$ from downtown Weetebula, $5 \mathrm{~km}$ from Tambolaka Airport, and $12 \mathrm{~km}$ from the Waikelo Harbor.
Currently, STKIP has 71 lecturers, 50 nonlecturing employees and 1377 students at 4 study programs: Primary School Teacher Education (PGSD), Indonesian Language Education, Mathematics Education, and Physics Education. Other donors have supported STKIP since its start in 2012 through investing in scholarships for lecturers, pedagogical technical support, and support for buildings of the college.

\subsection{Cooperation between STKIP Weetebula (Indonesia) and German partners}

Since its establishment in 2009, STKIP Weetebula needs donors to support STKIP Weetebula's operational activities. The main problem faced by STKIP is the limited number of lecturers to carry out the learning process in the classroom as well as personnel for academic administration.

Lecturers were young and fresh graduated with bachelor's certificate. Therefore, STKIP makes a proposal to the Misereor German to request experts and consultants who can assist and train lecturers and staff of STKIP Weetebula and also to fund their programs.

Misereor helped through the several projects and provide consultants. In general, a brief description according to consultant contract and implementation in practice are:

1. Providing advice on educational issues in the development of STKIP Weetebula; especially, a) in quality mangement of educational and classroom teaching methods, b) in the selection and support of new talents for lecturer positions in cooperation with participating universities outside Sumba. Contributing towards the development of teaching methodology based on employment contract. Increasing quality of education in STKIP and Sumbanese schools through research and training in priciples and methods of teaching and learning by

- Field trips to cooperating schools in Sumba;

- Finding new staff and providing introductory training,

- Establishing a taskforce (LP2) for quality in teaching;

- Evaluation of teaching methods and further trainings; 
- Conducting regular workshops on quality in teaching for lecturers;

- Assisting and evaluating lecturers in conducting these workshops for students;

- Evaluating the system of practical training for teacher students and planning a new structure.

2. Providing assistance in adapting the STKIP curriculum to the local context in Sumba by

- Attending workshops in curriculum development and accreditation process, and

- Participating in curriculum development.

3. Establishing a pilot project for continuous teacher training that enabling the alumni of STKIP to become a motor of innovation in Sumbanese schol system.

4. Supporting dialogue and further training through exchange of experience with other relevant educational organisations.

5. Supporting activities include:

- Developing a work program for implementation of new Misereor Project;

- Monitoring building projects and looking for new donors, writing proposals;

- Further language training;

- Providing procurements / infrastructure according to program contract;

- Planning of manpower requirements for STKIP / program contract.

To support the activities of the consultants, STKIP selected 3 lecturers and several staffs as a counterpart of the consultant to strengthen the quality of learning, curriculum improvement and alumni program.

In addition, to strengthen the capacity of lecturers and students of the mathematics study program, STKIP Weetebula developed a cooperation with FMD team from Osnabrück University Germany. They agreed to help prepare teachers and lecturers for STKIP Weetebula and implemented through a project supported also by Misereor. The STKIP Weetebula/Sumba (Indonesia) asks the FMD team of Osnabrück University for consulting in the following fields:

1. Support of the re-accreditation of the courses of study for teaching professions in mathematics (consulting of the rector and the vice rectors).

2. Support of the organization of research and development work of the newly founded 'Lembaga Matematika Kognitif', (Institute for Cognitive Mathematics):
- Selection and instruction of scientific personnel, particularly an institute board.

- Selection and instruction of student research assistants.

- Consulting in choosing suitable technical equipment and instruction of how to use them.

- Budget planning.

3. Instruction of junior staff members/trainees in the research and development work in Mathematics Education.

\subsubsection{The international cooperation of STKIP Weetebula.}

The title of these two international projects is: "Improving the quality and capacity of teacher training in East Indonesia at the Teacher Training College STKIP Weetebula, Sumba, Indonesia". The Misereor / KZE has supported the development of this newly established Teacher Training College in South-West Sumba District since 2012.

One of the objectives of the project is to improve the quality of education at STKIP Weetebula and Sumbanese schools because of research and training on principles and methods of teaching and learning. The indicator of this objective is that establishing a task force for quality in teaching for continuous research and training and has regular meetings (at least 10 times per year). In 2016. STKIP Weetebula established LP2 (Teaching Development Unit) that responsible to achieve the objective mentioned above. Through its program, STKIP Weetebula achieved its own curriculum, which is adapted to the local situation of Sumba. In order to achieve these objectives, the main strategy is to apply a new course of SPS (School Practice Seminar) in the STKIP curriculum.

SPS was initiated by a Pedagogic Advisor from AGEH (Arbeitsgemeinschaft für Entwicklungshilfe). The program is based on the observation, reflection and discussion with lecturers, students, staff and school teachers for almost 1 year. In short, the SPS compromises of these steps or phases:

1. Planning: Every student presents a lesson plan that is discussed with his / her SPS-group and the lecturer, they consider alternatives, the plan can be changed.

2. Monitoring: This (revised) lesson plan is implemented in a class of a cooperating school 
and observed / monitored by the SPS-group, the lecturer, and the mentor teacher.

3. Evaluating: All stakeholders discuss their observations. Together they find causes for the effects they have been watching. They discuss alternative approaches.

Preparation and implementation of SPS are as follows:

1. Internal Meeting of Head of STKIP Weetebula with SPS / LP2 Team.

2. SPS Preparation team meeting with study program leaders and lecturers.

3. SPS workshop with speakers from SPS / LP2 Team.

4. SPS workshop with school principals and mentor teachers.

5. SPS starts in March-July at campus and at school (1 lecturers and 1 mentor teacher assist 10-15 students).

6. Monitoring SPS at schools by LP2 Team.

7. Evaluation by students (questioner).

8. Evaluation by LP2 team and lecturers.

9. Preparation for SPS implementation next year.

The implementation of SPS follow several criteria below:

- $\quad$ SPS is a mandatory subject for every student

- $\quad$ Each study program has an SPS program

- A maximum of 15 students are involved in each group under the supervision of a lecturer and a mentor teacher

- $\quad$ SPS program runs for 1 semester (semester 6)

- $\quad$ SPS program runs in 4 lessons (50 minutes for each lesson), 2 lessons at STKIP for planning and assessment/evaluation, and 2 lessons in school for teaching practice. Figure 2 provide information about the schedule of SPS when runs at STKIP and school.

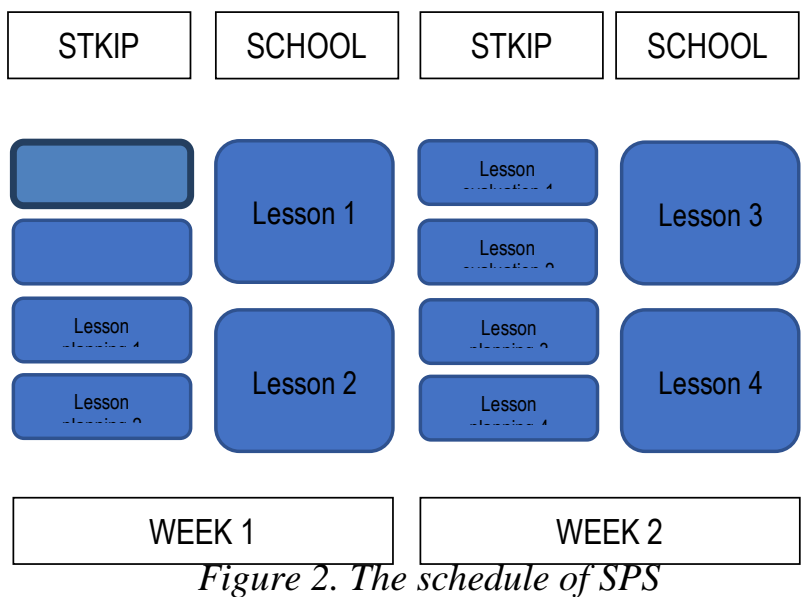

The people involved in the program come from different cultural background. The Table 3 below provides an overview of the responsibilities of person that involve in the SPS. By looking at the responsibilities of the people involved in the SPS, it will easier to describe the cross-cultural processes or occur between the people who come from different cultures background.

\section{Table 3. The Responsibilities of Person Involve in SPS.}

\begin{tabular}{|c|c|c|}
\hline $\mathbf{N}$ & $\begin{array}{l}\text { Person/ } \\
\text { position }\end{array}$ & Responsibilities/Duties \\
\hline 1 & $\begin{array}{l}\text { Lecturers/ } \\
\text { Supervisor }\end{array}$ & 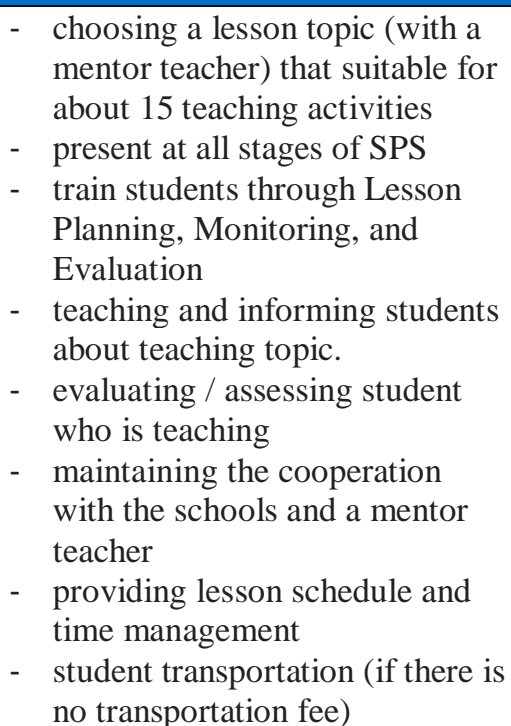 \\
\hline 2 & Student & 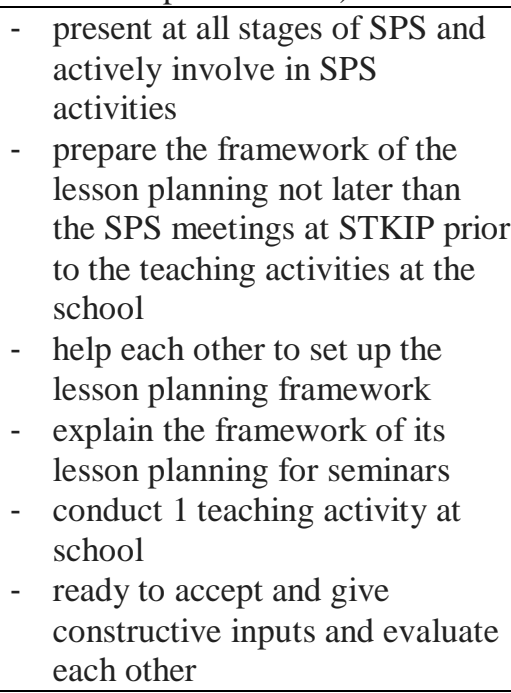 \\
\hline 3 & $\begin{array}{l}\text { Mentor } \\
\text { teacher }\end{array}$ & $\begin{array}{ll}\text { - } & \text { Prepare his/her classroom for } \\
\text { SPS } \\
\text { - } & \text { Provides a lesson topic for each } \\
\text { SPS's student } \\
\text { - } \quad \text { present at all stages of SPS at }\end{array}$ \\
\hline
\end{tabular}




\begin{tabular}{|c|c|c|}
\hline & & $\begin{array}{l}\text { school } \\
\text { - } \text { focus on teaching activities of } \\
\text { STKIP students } \\
\text { - informally provide constructive } \\
\text { ideas and criticisms to students }\end{array}$ \\
\hline 4 & $\begin{array}{l}\text { Task of } \\
\text { consultant } \\
\text { (LP2: } \\
\text { Learning } \\
\text { Developm } \\
\text { ent } \\
\text { Institution) }\end{array}$ & $\begin{array}{l}\text { - visit the SPS group at school (1- } \\
2 \text { times) for consultation / } \\
\text { assistance } \\
\text { - } \text { conduct workshops to plan and } \\
\text { evaluate the program } \\
\text { - } \text { continue workshops on the } \\
\text { quality of learning and adapting } \\
\text { for the needs of STKIP lecturers } \\
\text { - provide technical assistance } \\
\text { (such as photocopies etc.) if } \\
\text { necessary } \\
\text { - } \text { ready as a companion }\end{array}$ \\
\hline
\end{tabular}

\section{Mathematic project}

The project title is: "Development of a teaching research and training centre for teacher candidates in Sumba, Indonesia". The project has two specific objectives as agreed in the Project Contract: 1). Students and teachers possess skills and competences in metacognitive and discourse teaching methods in order to help improve their teaching at school and to help other teachers. 2). The establishment of a Teaching Research and Training Centre (TRTC), conditions and resources are created to set up a new, sustainable unit inside STKIP. TRTC's task is to develop methods to enable students and teachers to improve their teaching skills.

To carry out this activity, every year, the Team from FMD (Forschungsinstitut für Mathematikdidaktik e.V) from Germany University visits Sumba every year to conduct training and workshops for lecturers and STKIP students. The lecturers and students of STKIP Weetebula conduct the teaching at St. Aloysius Junior Secondary School (SMP in Weetebula) and St. Paul Junior Secondary School (SMP in Karuni). In SMP St. Aloysius, about 107 pupils have been involved (project classes since 2014) and 12 pupils at SMP St. Paul. FMD teams conduct supervision and monitoring during the teaching process in schools and then assist the lecturers and students of STKIP to prepare for further learning.

There are several people involved in the implementation of the activities of the program. Table 4 provides an overview of the people involved in the program based on the contract and responsibilities mention above, including the origin and ability of the English language they possess. It will then examine how people from different places and cultures interact with each other by reviewing the four Hofstede dimension cultures.

Table 4. Cooperation and Employee Programs (Lecturers and Staff of STKIP) who are in the International Cooperation Program.

\begin{tabular}{|c|c|c|c|c|c|c|}
\hline No & $\begin{array}{l}\text { Cooperation } \\
\text { Program }\end{array}$ & Employee & Position & $\begin{array}{l}\text { English } \\
\text { Proficiency }\end{array}$ & $\begin{array}{c}\text { Bahasa } \\
\text { Proficiency }\end{array}$ & $\begin{array}{l}\text { Country of Origin } \\
\text { (itland) }\end{array}$ \\
\hline & \multirow{16}{*}{$\begin{array}{l}\text { Cooperation } \\
\text { Misereor/KZE } \\
\text { Germany with } \\
\text { STKIP Weetebula/ } \\
\text { YAPNUSDA: } \\
\text { Project Title: } \\
\text { Improving The } \\
\text { Quality and } \\
\text { Capacity of Teacher } \\
\text { Training in East } \\
\text { Indonesia at the } \\
\text { Teacher Training } \\
\text { College STKIP } \\
\text { Weetrebula. } \\
\text { Duration: 1 } \\
\text { February 2016-31 } \\
\text { January 2018. }\end{array}$} & WYK & $\begin{array}{l}\text { ActingLegal } \\
\text { Holder }\end{array}$ & Good & Good & $\begin{array}{l}\text { Indonesia (Sumba } \\
\text { Island) }\end{array}$ \\
\hline & & PP & \begin{tabular}{l|} 
Program \\
Manager
\end{tabular} & Good & Good & Indonesia (dausal Island) \\
\hline & & $\mathrm{MA}$ & Expert & Good & Good & Indonesia (davos Island) \\
\hline & & FS & Expert & Good & Good & $\begin{array}{l}\text { Indonesia (Sumatera } \\
\text { Island) }\end{array}$ \\
\hline & & ATD & \begin{tabular}{l|} 
Curriculum \\
Program \\
Coordinator
\end{tabular} & Less & Good & $\begin{array}{l}\text { Indonesia (Sumba } \\
\text { Island) }\end{array}$ \\
\hline & & $\mathrm{KPN}$ & \begin{tabular}{l|} 
Alumni \\
Program \\
Coordinator
\end{tabular} & Leßs & Good & $\begin{array}{l}\text { Indonesia (Sumba } \\
\text { Island) }\end{array}$ \\
\hline & & JTA & Cashier & Poor & Good & $\begin{array}{l}\text { Indonesia (Sumba } \\
\text { Island) }\end{array}$ \\
\hline & & SMK & IT Staff & Les5 & Good & $\begin{array}{l}\text { Indonesia (Sumba } \\
\text { Island) }\end{array}$ \\
\hline & & AA & $\begin{array}{l}\text { Finance } \\
\text { Staff }\end{array}$ & Less & Good & $\begin{array}{l}\text { Indonesia(Sumba } \\
\text { Island) }\end{array}$ \\
\hline & & YN & $\begin{array}{l}\text { Administrati } \\
\text { on Staff }\end{array}$ & Poor & Good & $\begin{array}{l}\text { Indonesia (Sumba } \\
\text { Island) }\end{array}$ \\
\hline & & FTA & $\begin{array}{l}\text { Alumni } \\
\text { Program } \\
\text { Staff }\end{array}$ & Poor & Good & $\begin{array}{l}\text { Indonesia(Sumba } \\
\text { Island) }\end{array}$ \\
\hline & & VGR & $\begin{array}{l}\text { Finance } \\
\text { Staff }\end{array}$ & Poor & Good & $\begin{array}{l}\text { Indonesia (Sumba } \\
\text { Island) }\end{array}$ \\
\hline & & $A D R$ & Driver & Poor & Good & $\begin{array}{l}\text { Indonesia(Sumba } \\
\text { Island) }\end{array}$ \\
\hline & & BI & Consultant & Good & Average & Germany \\
\hline & & $\sqrt{D}$ & Consultant & Good & Average & Germany \\
\hline & & MF & $\begin{array}{l}\text { Pedagogic } \\
\text { Advisor }\end{array}$ & Less & Good & Germany \\
\hline \multirow[t]{6}{*}{2} & \multirow{6}{*}{$\begin{array}{l}\text { Mathematic Project } \\
\text { (Cooperation } \\
\text { Miserear/KZE } \\
\text { Germany with } \\
\text { STKIP Weatebula/ } \\
\text { YAPNUSDA) } \\
\text { Project Title: } \\
\text { Development of a } \\
\text { Teaching Research } \\
\text { and Training Cantre } \\
\text { for Teacher } \\
\text { Candidates in } \\
\text { Sumba, Indonesia. } \\
\text { Duration: } 2 \text { April } \\
\text { 2013-31 March } \\
\text { 2017. (Qsnabngick }\end{array}$} & WYK & $\begin{array}{l}\text { Acting Legal } \\
\text { Holder }\end{array}$ & Good & Good & $\begin{array}{l}\text { Indonesia (Sumba } \\
\text { Island) }\end{array}$ \\
\hline & & PP & $\begin{array}{l}\text { Program } \\
\text { Manager }\end{array}$ & Good & Good & Indonesia (Jaxk Island) \\
\hline & & $\mathrm{DA}$ & $\begin{array}{l}\text { Head of } \\
\text { LMK }\end{array}$ & Good & Good & $\begin{array}{l}\text { Indonesia (Sumba } \\
\text { Island) }\end{array}$ \\
\hline & & $\mathrm{MC}$ & Staff & Poor & Good & $\begin{array}{l}\text { Indonesia(Flores } \\
\text { Island) }\end{array}$ \\
\hline & & TWN & Staff & Poor & Good & $\begin{array}{l}\text { Indonesia (Sumba } \\
\text { Island) }\end{array}$ \\
\hline & & ER & Staff & Poor & Good & $\begin{array}{l}\text { Indonesia (Sumba } \\
\text { Island) }\end{array}$ \\
\hline & \multirow{5}{*}{$\begin{array}{l}\text { University Gemmany } \\
\text { as a third-party } \\
\text { partner of this } \\
\text { program). }\end{array}$} & $\mathrm{NL}$ & "Staff & Poor & 'Good' & $\begin{array}{l}\text { Indonesia (Flores } \\
\text { Island) }\end{array}$ \\
\hline & & $E C F$ & Consultarit & Good & Poor & Germany \\
\hline & & $\mathrm{CK}$ & Consultart & Good & Poor & Germany \\
\hline & & EN & Consultart & Good & Poor & Poland \\
\hline & & $\mathbb{M K}$ & $\begin{array}{l}\text { Pedagogic } \\
\text { Advis or }\end{array}$ & Less & Good & Germany \\
\hline
\end{tabular}




\section{The cooperation based on Hofstede's Culture Dimensions}

This part of paper discusses about the cooperation between Indonesian and Germany in two projects based on the cultural dimensions of Hofstede. The illustration on each dimension are based on the observations and experiences of the author on people that mentioned on Table 3 above.

Table 5. The cooperation between Indonesian and Germany in two projects based on the cultural dimensions of Hofstede

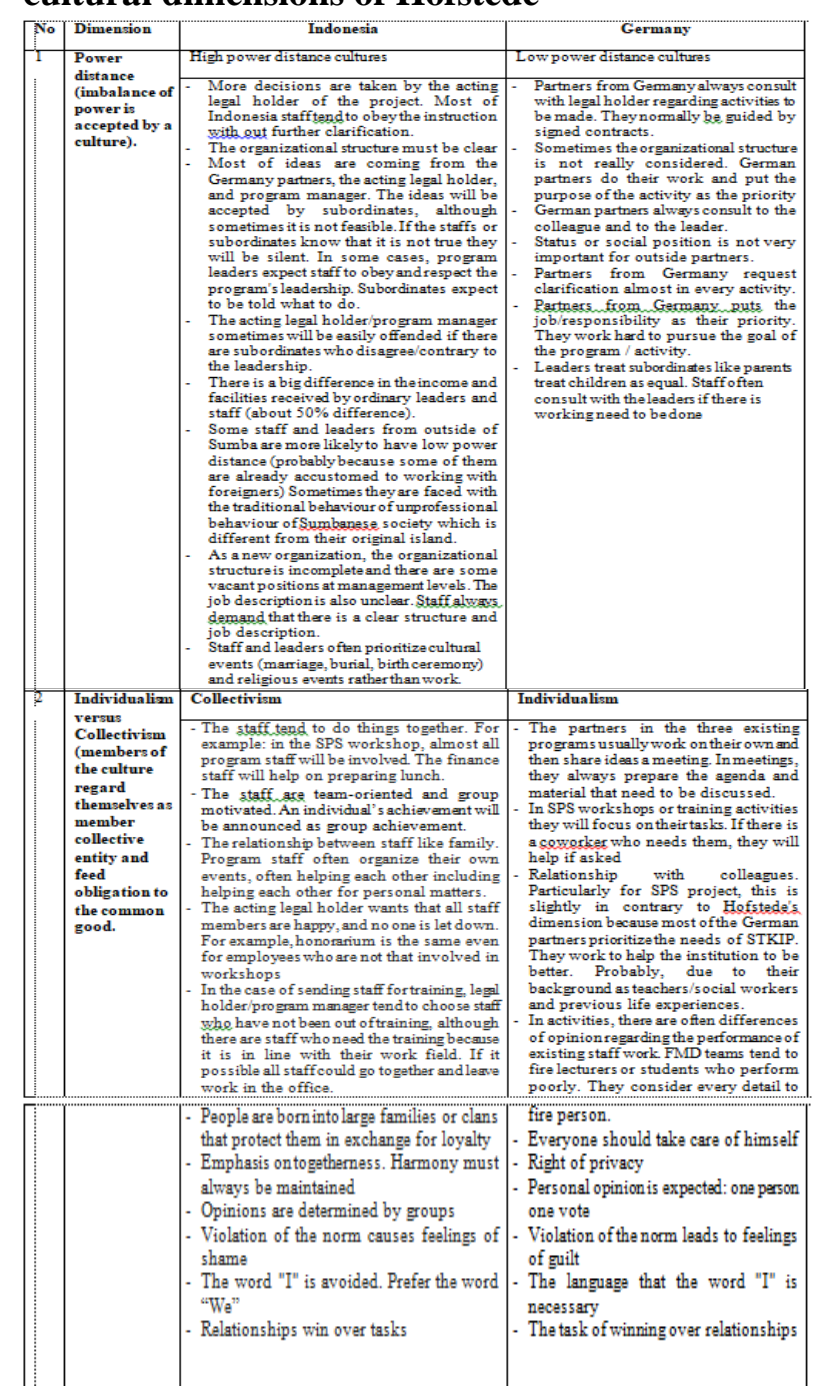

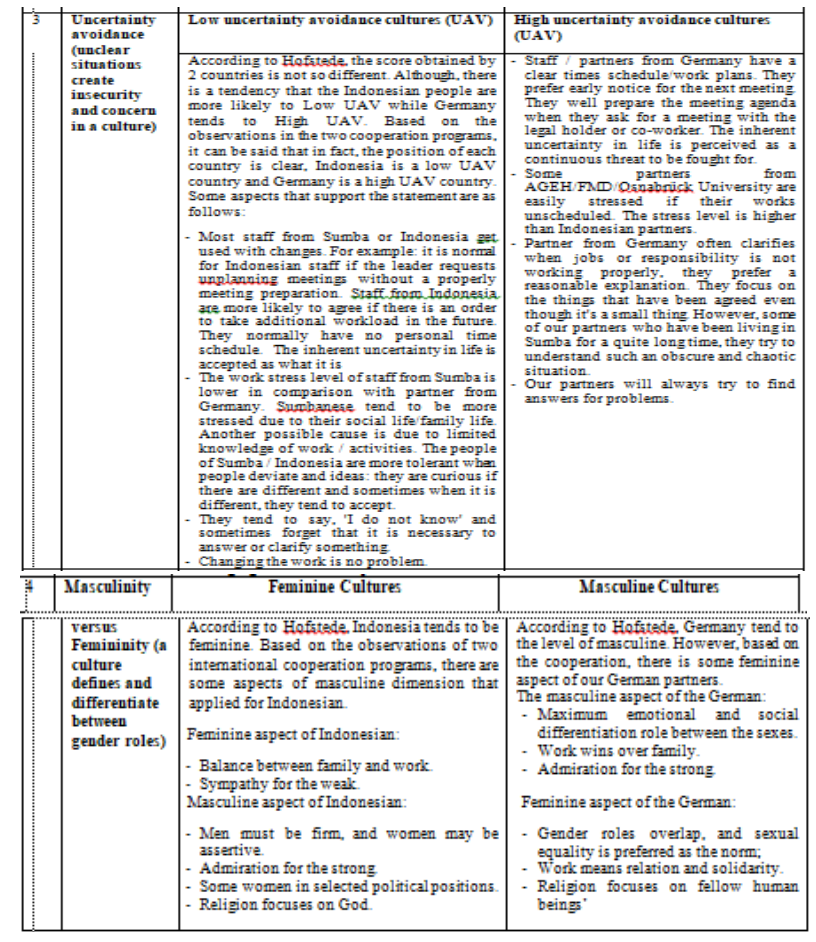

The difference in these cross-cultural approaches at STKIP Weetebula creates some challenges for employees that coming from different cultural background. Some team members view time differently, issues relating to planning, decision-making or project deadlines can often lead to frustrations caused by miscommunication and mismatched expectations. It will be different situation if multicultural team members have similar attitudes, expectation and motivation relate to those dimensions, then, the projects or activities can be relatively problem-free. For example, German partners who work on a STKIP's multicultural team can be frustrated by unpredicted meeting schedule with short notice information. Conversely, the Indonesian team members may feel that their counterparts come across as being pushy and fail to consider the harmony of the team.

In addition, for German partners, consider the time efficiency as a measurement of success. For example, if a project or activity is not completed by the agreed date, the institution reputation will suffer. However, some part of the Indonesian cultures takes a different approach to time management. They tend to favour the coordination of tasks rather than tackling them sequentially.

These are just a few examples that show how to attribute a great challenge to multicultural teams. The challenges and advantages that are 
different from those that work on. Through openness, communication process and some learned among employees from different cultures, multicultural teams can develop strategies for effective team working and productivity.

In fact, cross-cultural communication requires awareness of cultural differences because of what may be acceptable and natural in one country, can be confusing or even offensive in another.

\section{Daftar Pustaka}

De Mooij, M., (2004). Consumer behavior and culture: consequences from global advertising and advertising. Thousand Oaks, CA: Sage.

Hofstede, G., (1980). Culture's consequences: international differences in workrelated values. Beverly Hills, CA: Sage.

Hofstede, G. and Bond, M.H., (1988). The Confucius connection: from cultural roots to economic growth. Organizational Dynamics, pp 4-21.

Hofstede, G., (1994). Cultures and organizations: software of the mind. Harper-Collins Publishers. London.

Hofstede, G. J., and Minkov, M., (2010). Cultures and Organizations: Software of the Mind (Rev. 3rd ed.). McGrawHill. New York.

Jenks, Chris, 2013. Culture, Studi Kebudayaan. Translated from "Culture". Penerbit Pustaka Pelajar. Yogyakarta

Jones, M.L., (2007). Hofstede -culturally questionable? Oxford Business \& Economics Conference. Oxford, UK, pp 24-26.

Kirkman, B.L., Lowe, K.B. and Gibson,C.B., (2006). A quarter century of Culture's Consequences: a review of empirical research incorporating Hofstede's cultural values framework. Journal of International Business Studies, 37, pp 285-320.
Liliweri, A., 2003. Makna Budaya dalam komunikasi antarbudaya. LKiS Yoyakarta. Pp 120-127

Maheswaran, D. dan Shavitt, S., (2000). Issues and new directions in global consumer psychology. Journal of Consumer Psychology, 9 (2), pp 59-66.

Nasution, M. S. Albani, (2015). Ilmu Sosial Budaya Dasar. PT Raja Gravindo Persada Jakarta. Pp 16-17.

Sihombing S. Oktoria, and Pongtuluran Feriadi D., (2011). Pengidentifikasian Dimensi-Dimensi Budaya Indonesia: Pengembangan Skala Validasi. Journal dan Proceeding, 1(1). http://jp.feb.unsoed.ac.id/index.php/sca -1/article/view/87

Steenkamp, J.M.E., Hofstede, F. and Wedel, M., (1999). A cross-national investigation into the individual and national cultural antecedents of consumer innovativeness. Journal of Marketing, 63. pp 55-69. 